not common in most metamorphic or igneous rocks). But the increase in the isotope composition of meteoric waters with time means that low $\delta^{18} \mathrm{O}$ clays (grossly out of equilibrium with modern waters) must have formed in ancient and cooler weathering regimes.

The division between fields $\mathrm{B}$ and $\mathrm{C}$ does not require the rejection of the independent age constraints, because in most cases the only independent constraint is simply that the weathering is older than mid-Tertiary. The division among pre-mid Tertiary samples is made on isotope grounds because the low $\delta^{18} \mathrm{O}$ clays could not have formed during the comparatively warm climate of the late Mesozoic and early Tertiary in Australia. The isotope composition of the few samples of demonstrably pre-late Mesozoic age (such as kaolinite from regolith profiles beneath the Jurassic Wisanger Basalt, $+10.2 \%$ and Jurassic Algebuckina Sandstone, $+12.3 \%$ ) confirms the subdivision.

We are aware of the complexities involved in the palaeomagnetic dating of iron accumulations and, as indicated in our paper, we do not believe that there is necessarily a genetic or temporal link between the formation of a clay assemblage and an iron-rich zone in a regolith profile. We did not rely heavily on palaeomagnetically dated profiles for the reasons stated by Paton et al., but in cases such as the Morney profile in south-west Queensland ${ }^{13}$, the palaeomagnetic date can be taken as a minimum age for the development of the clay mineral assemblage.

With reference to the work of Paton et al. on the Cobar region, note that a kaolinitic sample collected from a roadcut $23 \mathrm{~km}$ south of Enngonia (which did not have any independent age control) yielded a $\delta^{18} \mathrm{O}$ value of $+18.1 \%$ (post midTertiary), consistent with the conclusions of those authors.

Finally, Paton et al. comment on the paucity of data points, particularly in the post-late Tertiary group, having previously described in detail the difficulties inherent in finding suitably unequivocal localities to sample. The post-late Tertiary samples we analysed were largely obtained from regolith developed on the late TertiaryQuaternary volcanic provinces of Victoria and north Queensland. If Paton et al. wish to point out other such unequivocal localities, we would be glad to sample them.

MiCHAEl I BiRD

Allan R Chivas

Research School of Earth Sciences,

Australian National University,

GPO Box 4, Canberra 2601, Australia

1. Bird, M.I. \& Chivas, A.R. Nature 331, 513-516 (1988).

2. Burges, A. \& Beadle, N.C.W. Aust. J. Sci. 15, 170-171 (1953).

3. Faniran, A. J. Geol. Soc. Aust. 18, 159-164 (1971).

4. Hunt, P.A., Mitchell, P.B. \& Paton, T.R. Geoderma 19, 105-121 (1977).
Bishop, P., Hunt, P.A. \& Schmidt, P.W. J. Geol. Soc. Aust. 29, 319-326 (1982).

6. Hunt, P.A. thesis, Macquarie Univ. (1985)

Langford-Smith, T. \& Dury, G.H. Am. J. Sci. 263 $170-190(1965)$

8. Dury, G.H. J. Geol. Soc. Aust. 13, 299-307 (1966).

9. Wasson, R.J., Hunt, P.A. \& Clarke, M.F. Geoderma 22, 137-159 (1979).

10. Exon, N.F., Langford-Smith, T. \& McDougall, I. J. Geol. Soc. Aust. 17, 21-30 (1970).

11. Bird, M.I. \& Chivas, A.R. Geochim, cosmochim, Acto (submitted).

2. Bird, M.I. \& Chivas, A.R. Chem. Geol. 72, 249-265 (1988).

13. Idnurm, M. \& Senior, B.R. Palaeogeogr. Palaeoclimatol. Palaeoecol. 24, 263-277 (1978).

\section{Origin of life}

SIR-Miller and Bada ${ }^{1}$ have made a valuable contribution to the understanding of the organic chemistry of high-temperature hydrothermal systems. They are, however, incorrect in citing my work ${ }^{2}$ as supporting the hypothesis that life began in vents at mid-ocean ridges ${ }^{3}$. This important hypothesis has stimulated much debate $e^{4}$ and is extremely interesting, but the evidence is strong $^{2,5,6}$, as Miller and $\mathrm{Bada}^{1}$ have confirmed, that conditions are probably too extreme in submarine ridge vents.

The much more likely candidate for our birthplace is in subaerial (that is, land) hydrothermal systems. In them, temperatures at high level are commonly around $40{ }^{\circ} \mathrm{C}$, with $\mathrm{pH}$ fluctuating, often even mildly alkaline. Closely juxtaposed parts of a system may vary greatly in temperature, and both water-dominated and relatively dry gas-dominated conditions are possible, often in rapid succession in the same place. There may be rapid influx of fluid of very different chemistry, from considerable depth. Many potential mineral catalysts occur. It is for these reasons that I concluded ${ }^{2.5 .6}$ that the likely setting of an RNA world would be in a subaerial, meteoric water hydrothermal system. Perhaps nowhere else in the Archaean world were conditions so favourable for that extraordinary event, the origin of life.

Department of Geological Sciences,

University of Saskatchewan,

Saskatoon S7W OW0, Canada

1. Miller, S.L. \& Bada, J.L. Nature 334, 609-611 (1988)

2. Nisbet, E.G. The Young Earth (Allen and Unwin, Winchester, Massachusetts, 1987)

3. Corliss, J.B., Baross. J.A. \& Hoffman, S.E. Oceanologica Acta 4, Suppt. 59-69 (1981).

4. Joyce, G. Nature 334, 564 (1988)

5. Nisbet, E.G. Nature 321, 206 (1986)

6. Nisbet, E.G. Episodes $9,83-90(1986)$

Miller ANd BADA REPly - Nisbet proposes that the origin of life took place in $40^{\circ} \mathrm{C}$ vent waters rather than $350^{\circ} \mathrm{C}$ vents. Russell et al. ${ }^{2}$ have also claimed that lukewarm vent waters were the site of important prebiotic reactions. The vent waters that are referred to are apparently hydrothermal waters cooled by mixing with sea water or by loss of heat to rocks. Because the high-temperature conditions would decompose all the organic compounds, the vent waters mixed with sea water would have less organic material than the ocean as a whole.

It is not clear what is to be gained from this process over heating parts of the primitive ocean to $40^{\circ} \mathrm{C}$ on a beach or in a lagoon. An alternative is to heat the primitive sea water to $40^{\circ} \mathrm{C}$, but not much higher, by circulating it through heated rocks. This apparently does not occur near submarine vents, but may take place near volcanoes (H. Craig, personal communication). Again there seems little to be gained by invoking this type of process. The chemical reactions taking place at $40^{\circ} \mathrm{C}$ are more rapid but still similar to those at $0^{\circ} \mathrm{C}$, with a few exceptions (for example, template polymerizations may not work at $40^{\circ} \mathrm{C}$ because of the melting of the helix). Taking the heat of activation of a reaction as $20 \mathrm{kcal} \mathrm{mol}^{-1}$ and assuming that 1 part in $10^{5}$ of the ocean is at $40^{\circ} \mathrm{C}$, then $99.9 \%$ of the reaction would occur at $0^{\circ} \mathrm{C}$ and only $0.1 \%$ at $40^{\circ} \mathrm{C}$.

Russell et al. refer to the reported detection of glycine in Red Sea hydrothermal brines $^{2}$ as evidence that a biotic synthesis occurs in mild hydrothermal vents. This glycine is a contaminant, however, which bleeds from the Chelex resin ${ }^{3.5}$ employed in the analytical scheme. In addition, no other amino acids were reported ${ }^{2}$, which would be usual for a prebiotic synthesis.

If lukewarm vent water, and not the ocean as a whole, came in contact with minerals that catalysed critical prebiotic reactions, as proposed by both Nisbet and Russell et al., our argument could change. It is not feasible to evaluate this possibility until the minerals and reactions are named. It is to be noted that an important role in prebiotic chemistry for minerals and clays has so far not been demonstrated. As for the role of hydrophobic surfaces a primitive oil slick ${ }^{6}$ may have been more important than the mineral surfaces suggested by Russell $\mathrm{et}$ al.

Department of Chemistry

Stanley L. Miller

JEFFREY L. BADA

Scripps Institution of Oceanography,

University of California, San Diego,

La Jolla, California 92093, USA

1. Russell, M. J.. Hall, A. J., Cairns-Smith, A. G. \& Brat erman, P. S. Nature 336, 117 (1988)

Ingmanson, D. E. \& Dowler, M. J. Nature 286, 51-52 (1980)

3. Lee, C. L. \& Bada, J. L. Earth planet. Sci. Lett. 26, 61-68 (1975).

4. Gardner. W. S. Mar. Chem. 6. 15-26(1978)

5. Bada, J. L.. Hoopes, E. \& Ho, M.-H. Earth planet. Sci. Lett. 58, 276-284 (1982).

6. Lasaga, A. C., Holland. H. D. \& Dwyer, M. J. Science 174, 53-55 (1971).

\section{Barnacle taxonomy}

SIR-Crisp and Fogg ${ }^{1}$ attack what they consider "mere changes of opinion" in establishing and changing names of taxa above the species level. To alleviate attendant inconveniences, at least among the barnacles, they offer a remedy of 